\author{
ADAM BOBRYK \\ UNIWERSYTET \{RZYRODNICZO-HUMANIST YCZNY W SiEDLCACH \\ E-MAIL: ADAM.BOBRYK@GMAIL.COM
}

\title{
CZAS PRZEŁOMU. POGRANICZE LITEWSKO-POLSKIE W PERSPEKTYWIE DZIAŁAŃ KGB LSRR W LATACH 1979-1983 NA TERENIE REJONU ŁOŹDZIEJSKIEGO
}

\section{Uwagi wstępne}

W wyniku II wojny światowej istotnej przemianie uległy granice Polski. W efekcie zmieniła się też część państw granicznych, co było w pewnym stopniu związane $\mathrm{z}$ aneksją przez Związek Socjalistycznych Republik Radzieckich (ZSRR) między innymi Republiki Litewskiej (RL). Konsekwencją tych działań było zasadnicze przekształcenie ustrojów państw regionu, jak też relacji między nimi. Granica Polski z Litwą została skrócona z $525 \mathrm{~km}$ do $104 \mathrm{~km}$, pozostawiając Wileńszczyznę poza obszarem Polski [Eberhardt 1997: 93; Błaszczyk 1992: 13-14]. Nowa linia graniczna określona została w umowie polsko-radzieckiej zawartej 16 sierpnia 1945 roku w Moskwie, opierając się na nieco skorygowanej Linii Curzona [Ślusarczyk 1994: 75-76].

Litewską Socjalistyczną Republikę Radziecką (LSRR), którą utworzono 21 lipca 1940 roku, po zajęciu RL przez Armię Czerwoną, 3 sierpnia tego roku włączono oficjalnie w skład ZSRR. Po wybuchu wojny niemiecko-radzieckiej 22 czerwca 1941 roku znalazła się pod okupacją III Rzeszy. Tereny te ponownie zajęte zostały przez ZSRR w latach 1944-1945. Po aneksji Litwy przeprowadzono szereg radykalnych zmian systemowych. Zlikwidowano prywatną własność ziemi, zakładów produkcyjnych, przystąpiono do intensywnej indoktrynacji społeczeństwa w duchu idei komunistycznych, dążono do zmarginalizowania życia religijnego oraz wyeliminowania jakiegokolwiek działania obywateli, które nie byłoby sankcjonowane przez państwo. Spotykało się to, zwłaszcza w pierwszym dziesięcioleciu, z silnym oporem społecznym, który próbowano przełamać poprzez system represji [Anušauskas 2006; Tininis 2009]. 
W życiu publicznym funkcjonowało szereg ograniczeń, które ukierunkowane były na kształtowanie postaw uznających prymat Komunistycznej Partii Związku Radzieckiego (KPZR), jej wszystkich założeń ideologicznych oraz realizowanej przez państwo polityki. W Konstytucji ZSRR z 1977 roku określono to w sposób następujący „Najwyższym celem państwa radzieckiego jest zbudowanie bezklasowego społeczeństwa komunistycznego, w którym rozwinie się społeczny, komunistyczny samorząd. Głównymi zadaniami socjalistycznego państwa ogólnonarodowego są: zbudowanie materialno-technicznej bazy komunizmu, udoskonalenie socjalistycznych stosunków społecznych i przekształcenie ich w stosunki komunistyczne, wychowanie człowieka społeczeństwa komunistycznego, podwyższenie materialnego i kulturalnego poziomu życia ludzi pracy, zapewnienie bezpieczeństwa kraju, przyczynianie się do utrwalania pokoju i rozwijania międzynarodowej współpracy" [Konstytucja 1978: 40].

Dla osiągnięcia założonych celów stosowano wielokierunkowe działania. Dotyczyło to praktycznie wszystkich sfer życia. Były to więc nie tylko bezpośrednie oddziaływania instytucji o charakterze politycznym, ale również edukacyjnym, informacyjnym, kulturalnym. Ingerowano także w obszar życia prywatnego. Związane to było z izolacją obywateli od świata zewnętrznego. Wszelkie kontakty z innymi krajami, jak też kulturą masową dominującą $w$ tych państwach, były bardzo ograniczone i podlegały szczególnemu nadzorowi. Obawiano się bowiem, iż będzie to wpływało na osłabienie systemu. Obostrzenia dotyczyły nie tylko jakichkolwiek relacji z państwami demokracji zachodniej, ale również należącymi do tego samego bloku politycznego, jak wówczas określono Kraje Demokracji Ludowej. Pomimo szeregu ograniczeń w zakresie praw człowieka i militaryzacji społeczeństwa w oficjalnej propagandzie upowszechniano tezy, iż Związek Radziecki jest „przodującą demokracją świata” i „awangardą w walce o pokój” [Aleksandrow 1949; Кравченко 1980]. Przy wykorzystaniu także mechanizmów indoktrynacji, ukierunkowywano tak procesy socjalizacji politycznej, by prowadzić do zachowań politycznych ściśle określonych przez rządzącą partię. Oczekiwano, aby jednostki przyjmowały role polityczne zgodne z potrzebami systemu. Jak zauważa Jerzy Wiatr „Oddziaływanie socjalizacyjne systemu społeczno-politycznego dokonuje się dwojako: bezpośrednio - przez propagowanie określonych treści poznawczych i emocjonalnych, popularyzowanie wzorów i postaci, które chciałoby się uczynić przykładem dla innych itp., oraz pośrednio - przez stwarzanie warunków działania, w których wzrasta skłonność do postępowania w taki, a nie inny sposób" [Wiatr 2009: 289-290]. 
Pożądane zachowania uzyskiwano nie tylko przez kreowanie oczekiwanych wzorów postępowania, ale w dużym stopniu w wyniku działania aparatu represji. W ZSRR rozbudowany był system obozów pracy tak zwany GUŁAG, do połowy lat pięćdziesiątych masowo stosowano również zesłanie w głąb kraju, jako instrument zastraszenia społeczeństwa, a wolność słowa ograniczona była do tego stopnia, iż opowiadanie anegdot o odcieniu politycznym zagrożone było karą więzienia [Солженицын 2009]. Jedną ze służb powołanych do walki z działalnością antyradziecką, przejawami aktywności narodowej, działalnością poza systemową, w której kompetencjach znalazł się również wywiad i kontrwywiad był Komitet Bezpieczeństwa Państwowego (KGB) - Комитет государственной безопасности (Valstybès saugumo komitetas). Działał on w latach 1954-1991. W jego ramach funkcjonowały poszczególne struktury republikańskie, które jednak nie były autonomiczne i realizowały zadania wyznaczone przez władze centralne, $\mathrm{z}$ uwzględnieniem specyfiki lokalnej [Anušauskas 2008].

Litewska Socjalistyczna Republika Radziecka posiadała pewne atrybuty samodzielności w ramach państwa związkowego. Działał parlament, rząd, organy administracji terenowej, oprócz związkowych używano także republikańską flagę i godło. Nadano formalne uprawnienia dla języka litewskiego (urzędowym był rosyjski). Wydzielono sekcje republikańskie różnorakich instytucji ogólnoradzieckich. Było to jednak pozorne. Faktycznie władza państwowa w ZSRR była mocno zhierarchizowana, a zakres swobody poszczególnych republik był niewielki. Litwa, podobnie jak Łotwa i Estonia, miały jednak nieco mniej ograniczeń niż pozostałe części Związku Radzieckiego. Dotyczyło to głównie życia religijnego i aktywności kulturalnej. Nie oznaczało to jednak swobody działania [Mikłaszewicz 2001].

Republika Litewska znajdowała się również w pewnym specyficznym położeniu, gdyż część jej granic, była jednocześnie zewnętrznymi ZSRR. Dotyczyło to odcinka granicy z Polską Rzeczpospolitą Ludową (PRL). Jego kontrola podlegała pod władze centralne. Brak było tu stałych przejść granicznych. Jedyne drogowe Ogrodniki-Łoździeje (Lazdijaji), służyło do przejazdu delegacji i grup zorganizowanych oraz dyplomatów po wcześniejszych uzgodnieniach. Zabezpieczenie tego terenu realizowały wojska pogranicza 95 Kaliningradzkiego Oddziału Nadbałtyckiego Okręgu Wojennego. Łoździeje znajdowały się na 21 odcinku. W terenie były rozwinięte również inne jednostki, jak na przykład wydzielona 902 radiolokacyjna kompania [LYA 1979: 1].

Trafnie zauważa Piotr Sztompka, że „tak jak nie ma «my» bez «oni», tak nie ma mojej przestrzeni społecznej bez jakichś przestrzeni «ich», obcych, 
tych którzy są poza granicą naszej wspólnoty, gdzieś w odległej przestrzeni międzyludzkiej. Przestrzeń to bliskość, ale także dystans. I przestrzeń to granice, materialne, mentalne lub symboliczne wyznaczniki dystansu. Najbardziej oczywistym przykładem granic są granice międzypaństwowe" [Sztompka 2012: 140]. Przy granicach zawsze występuje obszar pośredni, który wyróżnia się nieco inną specyfiką. Pogranicza są różnorodne. Natomiast w odniesieniu do analizowanego terenu, za Andrzejem Sadowskim, moglibyśmy je opisać jako położone na peryferiach centrów politycznych i państwowych. W pewnym sensie również społecznych oraz kulturowych. Pogranicze jest więc obszarem obok granic polityczno-administracyjnych. To „terytorium zamieszkałe przez jeden naród (grupę etniczną), ulokowane obok granicy państwowej, która oddziela dwa zasadnicze narody, grupy etniczne, których ewentualne wzajemne oddziaływanie odbywa się poprzez granicę państwową lub obejmuje różne doświadczenia mieszkańców, stan ich świadomości w kontekście zamieszkiwania w sąsiedztwie lub obok granicy" [Sadowski 2014:105]. Należy tutaj jednak podkreślić, iż Sadowski postrzega taki przypadek zdecydowanie w kategoriach peryferii.

Od 1962 roku, na mocy uchwały Komitetu Centralnego (KC) litewskich struktur KPZR, rozpoczęto współpracę przygranicznych jednostek administracyjnych. Ze strony LSRR uczestniczyły w tych działaniach między innymi rejony wyłkowyski (Vilkaviškis), mariampolski (Marijampole - wcześniej Kapsukas), łoździejski (Lazdijai), orański (Varèna) i olicki (Alytus). Jedną z form ich realizacji były wymiany delegacji, współzawodnictwo pracy, uczestnictwo w wydarzeniach o charakterze ideologicznym [Bobryk 2005: 87-89]. Było to zgodne z duchem uchwały KC, w której stwierdzano, iż celem współpracy ma być „wymiana doświadczeń budownictwa komunistycznego i socjalistycznego" [Požarskas 1984: 85]. Jak ocenia Piotr Łossowski, ówczesne oficjalne kontakty charakteryzowały się pomijaniem „drażliwych spraw z przeszłości czy też nie rozwiązanych współczesnych” [Łossowski 1991: 89]. Istotna w tym kontekście staje się więc uwaga Grzegorza Babińskiego, który stwierdził „Sąsiedztwo to nie tylko zamieszkiwanie w pobliżu i wzajemne postrzeganie. To wszak także szeroko rozumiany obszar kontaktów i wzajemnych relacji w sferze ekonomicznej, handlowej, współpracy i konkurencji, wchodzenia w różne sytuacje konfliktowe i drogi wychodzenia z tych sytuacji” [Babiński 2015: 54].

Przy granicy z PRL znajdowały się trzy rejony LSRR. Były to wyłkowyski, mariampolski i łoździejski. Najdłuższy, gdyż 46-kilometrowy odcinek 
granicy z Polską przypadał na tę ostatnią jednostkę administracyjną. $\mathrm{Na}$ jej terenie położone było także przejście graniczne, które nie obsługiwało bieżącego ruchu, ale stwarzało możliwość przejazdu po spełnieniu określonych procedur. Jak wynika ze spisu powszechnego z 1979 roku rejon zamieszkiwały 38702 osoby. Z tej liczby Litwinów było 37702 (97,4\%), Rosjan 513 (1,3\%), Polaków 343 (0,9\%), Białorusinów 29 (0,1\%), innych 115 (0,3\%) [Eberhardt 1997: 207]. Działały tam 2 miejskie i 14 wiejskich rad deputowanych ludowych. Funkcjonowało 17 kołchozów, 3 sowchozy i 1 goschoz. Było też 10 średnich i 14 ośmioklasowych szkół [LYA 1979: 2]. Rejon charakteryzował się przede wszystkim produkcją rolniczą, ze szczególnym profilem dotyczącym ziemniaków, mleka i mięsa. Jednocześnie KGB odnotowywało stały spadek ludności poprzez wyjazdy młodzieży do większych centrów przemysłowych [LYA 1980: 1].

Pomimo funkcjonowania PRL i ZSRR w jednym bloku politycznym, wyraźnie ze strony państwa radzieckiego odczuwalny był pewien dystans i ograniczony zakres zaufania. Dlatego dążono do faktycznej izolacji społeczeństw. Organizowano natomiast pozorne inicjatywy mające świadczyć o wzajemnym braterstwie i przyjaźni. Faktycznie jednak granica dzieliła, mając uniemożliwić swobodny przepływ ludzi i idei. Na pograniczu litewsko-polskim dodatkowo dochodził czynnik świadomości trudnych wzajemnych relacji w przeszłości między Litwinami i Polakami. Składały się na to walki o granice, odmienne oceny przynależności terytoriów, doświadczenie zerwania stosunków w okresie międzywojennym, pamięć kształtowania negatywnych stereotypów drugiej strony [Buchowski 2006]. Należy uwzględnić również fakt, zachodzących na początku lat osiemdziesiątych przemian politycznych w Polsce [Fedorowicz 2008].

Strajki w latach 1980-1981, powstanie pierwszego niezależnego związku zawodowego "Solidarność”, postulaty demokratyzacji życia, funkcjonowanie drugiego obiegu wydawniczego, rozwój życia religijnego po wyborze kardynała Karola Wojtyły na papieża, wzbudzały duże zaniepokojenie władz radzieckich. Obawiały się one przeniesienia tych tendencji na teren ZSRR, a zwłaszcza LSRR. Dlatego w tym czasie podjęto szereg nowych działań mających ograniczyć i tak dość umiarkowane kontakty. Miały one wyeliminować jakiekolwiek próby upowszechniania tendencji, które wystąpiły w Polsce, na terenach przygranicznych, gdzie znacznie łatwiej przenikały informacje poprzez możliwość odbioru telewizji i radia drugiej strony. 


\section{Granica jako kordon}

Komitet Bezpieczeństwa Państwowego podkreślał iż, „Łoździejski jest pogranicznym rejonem co wywiera istotny wpływ na sytuację operacyjną" [LYA 1981b: 1]. Skalę wzajemnych kontaktów ukazuje ruch na przejściu granicznym. W latach siedemdziesiątych pomimo niewielkiej liczby osób ją przekraczających obserwowano stały wzrost. Przykładowo, w 1976 było to 939 osób, 1977 - 1598, 1978 - 3798, 1979 roku 4185 [LYA 1979: 2.]. W rejonie łoździejskim mieszkały 4 osoby (w 1983 roku 3 [LYA 1983b: 2]) sądzone za nielegalne przekroczenie granicy [LYA, 1979: 1-2]. Uwzględniając, iż od 19 lipca do 3 sierpnia 1980 roku w Moskwie zaplanowano Letnie Igrzyska Olimpijskie, przewidywano, iż zwiększy się liczba osób przekraczających na tym odcinku granicę. By nie dopuścić przy tym do "prób wwozu ideologicznie szkodliwej i religijnej literatury oraz wywozu za granicę oszczerczych materiałów” kierownictwo Rejonowego Komisariatu KGB poleciło „utrzymywać ścisły kontakt z oficerami P[rzejścia] G[ranicznego] nadzorującymi ruch na granicy" [LYA 1979: 6].

Życie społeczne polega na nieustającej wymianie [Mendras 2004: 159]; KGB prowadziło zaś działania zmierzające do ograniczenia zakresu tego procesu, a zwłaszcza wyeliminowania niekontrolowanych przez władze kontaktów i zachowań. Na 1980 rok w rejonie łoździejskim jako pierwszoplanowe zadania przyjęto „organizację niezawodnego agenturalno-operacyjnego zabezpieczenia ochrony odcinka granicy państwowej”, „niedopuszczenie zdrady Ojczyzny poprzez ucieczkę za granicę”, „stłumienie w rejonie antyradzieckiej zorganizowanej działalności klerykalnych i nacjonalistycznych elementów oraz poszukiwanie autorów i wydawców nielegalnych wrogich wydań, „odpór akcjom dywersji ideologicznej służb specjalnych przeciwnika i uprzedzenie szkodliwych politycznie przejawów" [LYA 1979: 3]. Szczególną uwagę operacyjną polecono zwrócić na okolice wsi Kuciany (Kučiūnai), gdzie wcześniej wykryto kanał przerzutowy, jak to określono „wykorzystywany przez bandy burżuazyjnych nacjonalistów i kontrabandystów" [LYA 1979: 5].

Obawiając się skutków bezpośrednich kontaktów mieszkańców Polski i Litwy w warunkach protestów społecznych w PRL, zdecydowanie ograniczono możliwość wjazdu na teren LSRR. Już 27 sierpnia 1980 roku, na miesiąc zamknięto przejście graniczne w Łoździejach. Ogólnie w ciągu całego roku w sprawach prywatnych przyjechało do rejonu 24 polskich obywateli, a wyjechało do Polski 44 mieszkańców. Jednocześnie zgody na 
wyjazd odmówiono 27 osobom, a przyjazdu 53 [LYA 1980: 3]. Oceniano, iż znacznie zmniejszyła się liczba osób przyjeżdżających z PRL do rejonu w sprawach prywatnych. Od września takie wizyty całkowicie ustały [LYA 1981a: 3]. Można przypuszczać, iż było to konsekwencją działań strony radzieckiej. Natomiast przez przejście graniczne przejechało 4712 osób, z czego 2693 było polskimi obywatelami. Pomimo wprowadzonych ograniczeń odnotowano wzrost, który był skutkiem zwiększonego ruchu związanego $\mathrm{z}$ olimpiadą $\mathrm{w}$ Moskwie i wymianą o charakterze ideologicznym. Przykładowo, 300 Polaków przybyło w sposób zorganizowany na uroczystości Dnia Zwycięstwa 9 maja [LYA 1980: 6]. Jednakże po wydarzeniach sierpniowych w PRL, możliwości przejazdu przez punkt graniczny w Łoździejach zostały mocno ograniczone.

W zakresie zadań dotyczących granicy w planach wyznaczonych na 1981 rok, KGB wyznaczyło kolejne działania. Świadczyły one o wzroście obaw dotyczących sytuacji międzynarodowej, co mogłoby odbić się również na stabilności funkcjonowania państwa radzieckiego. Jednym z pierwszoplanowych zadań uznano „Niedopuszczenie przeniknięcia przez granicę do naszego kraju wrogich wywiadowców i agentów, nielegalnej dostawy w ZSRR antyradzieckiej literatury, środków i przedmiotów, które mogą być wykorzystane w celu podburzania, wywozu za granicę oszczerczych materiałów" [LYA 1981a: 3].

W 1981 roku w związku z zachodzącymi w Polsce wydarzeniami praktycznie uniemożliwiono wyjazdy o charakterze nieoficjalnym. Nikt z mieszkańców rejonu nie udał się do sąsiedniego kraju, a tylko 4 obywateli PRL odwiedziło przygraniczny teren. Przerwana została również wymiana delegacji. Interesujące, iż jednocześnie zezwolono na wyjazd 2 osób do Kanady i 1 do Australii [LYA 1981b: 3]. Po wprowadzeniu stanu wojennego w Polsce (13 grudnia 1981), wznowiono w ograniczonym zakresie wymianę delegacji. Do PRL, w 1982 roku, wyjechało 65 osób w 18 grupach. Z Polski przyjechały 23 delegacje, w których uczestniczyły 122 osoby [LYA 1982b: 3].

W 1983 roku nieco wzrosła skala wymiany delegacji. Przez punkt graniczny w Łoździejach do PRL udało się 29 delegacji o łącznej liczebności 189 osób. Natomiast do ZSRR wjechało 36 delegacji z 774 osobami [LYA 1983b: 2]. Wyraźnie zaznaczała się tendencja do asymetrii w zakresie zarówno liczby delegacji jak i składu jej uczestników. Wynikało to niewątpliwie z nieufności władz radzieckich, które obawiały się niepożądanego oddziaływania życia społecznego w Polsce na swoich obywateli. Poprzez ograniczenie zakresu wyjazdów, zmniejszano potencjalne zagrożenie. Nie- 
mniej należy odnotować, iż bezpośrednio po zawieszeniu stanu wojennego w PRL (31 grudnia 1982), a następnie jego zniesieniu (22 lipca 1983) zakres wzajemnych kontaktów nie wrócił do poprzedniego poziomu.

W LSRR, jak i w całym ZSRR, panowała psychoza zagrożenia zewnętrznego. Obawiano się przenikania szpiegów, dywersantów, sabotażystów, osób godzących w podstawy ustroju. Dlatego szczególną, a wręcz nadmierną uwagę, przywiązywano do ochrony terytorium, starając się za wszelką cenę wyeliminować możliwość przedostania się jakiejkolwiek niepożądanej osoby. Do zabezpieczenia granicy, by uniemożliwić jej nielegalne przekroczenie, angażowano nie tylko wojsko, ale również milicję, sieć agenturalną, Ochotnicze Drużyny Ludowe (zbliżone celem działania do polskiej Ochotniczej Rezerwy Milicji Obywatelskiej) oraz mieszkańców przygranicznych miejscowości. Skalę tych działań określono w raporcie z 1980 roku. Stwierdzano w nim „W zadaniu operacyjnego zabezpieczenia granicy państwowej z ogólnej liczby 52 agentów Komisariatu Rejonowego wykorzystywano 27. W tym celu w 1980 r. zwerbowano 2 nowych wspólpracowników (...). Aktualnie zadania w zakresie ochrony granicy realizuje 78 zaufanych osób, z nich 4 pozyskaliśmy w 1980 r. Do tych zadań angażujemy 349 ludowych drużynników, $13 \mathrm{O}$ [chotniczych] D[rużyn] L[udowych] przygranicznych gospodarstw i miasta Łoździeje" [LYA 1980: 4]. Kontrwywiadowcze zabezpieczenie granicy KGB prowadziło przy ścisłym współdziałaniu ze specjalnym oddziałem wywiadu jednostki wojskowej 2497 [LYA 1981b: 3]. W 1983 roku z ogólnej liczby 53 agentów do zabezpieczenia granicy skierowano 26 . Razem z nimi na tym odcinku aktywnych było 80 zaufanych osób oraz 16 Ochotniczych Drużyn Ludowych grupujących 302 osoby [LYA 1983b: 4].

Funkcjonariusze KGB prowadzili również wykłady i inne formy oddziaływania ideologicznego w zakładach pracy poświęcone „politycznej czujności ludzi radzieckich i konieczności okazania pomocy w ochronie granicy państwowej”. Jak wykazano, w 1980 roku zostało przeprowadzonych 8 takich wykładów i 22 biesiady oraz opublikowano 2 artykuły w gazecie rejonowej [LYA 1980: 4]. Rok później odbyło się 11 wykładów i 18 biesiad [LYA 1981b: 3]. W 1982 przeprowadzono 12 wykładów i 11 biesiad [LYA, 1982b: 3]. W następnym roku zaś podjęto po 12 takich działań [LYA 1983b: 4]. Wyraźnie postrzegano pogranicze w kategoriach pewnej ideologii. Była to wizja kordonu oddzielającego przed otaczającym światem, który stanowi zagrożenie. Dążono więc, by jak największa grupa mieszkańców, a docelowo nawet wszyscy włączali się w jej zabezpieczenie. Jak zauważa Grzegorz 
Babiński „Postrzeganie pogranicza jako ideologii wiąże się z przypisywaniem obszarom pogranicza i zamieszkującym je ludziom jakiejś szczególnej roli, powinności, czasami wręcz misji, na tym obszarze lub w stosunku do obszarów leżących po obu stronach pogranicza. Ideologia jest zawsze czyjąś ideologią i bardzo często ideologia pogranicza nie była ideologią ludzi i zbiorowości tam właśnie zamieszkałych" [Babiński 1994: 16-17].

Pomimo licznych zabezpieczeń, zdarzały się przypadki prób nielegalnego przekraczania granicy z Polską. Nie wszystkie miały charakter celowy, ale traktowane były jako zagrożenie dla państwa. W 1980 roku, 22 kwietnia, uczeń jednej ze szkół w Łoździejach, przy użyciu drabiny pokonał zabezpieczenia graniczne i przedostał się do PRL. Następnego dnia podczas powrotu został pojmany przez wojska pogranicza ZSRR. Dwukrotnie zatrzymana (27 kwietnia i 23 sierpnia) na radzieckim pasie granicznym była 70-letnia obywatelka Polski narodowości litewskiej, mieszkająca w Sejnach. Jak twierdziła, było to skutkiem zagubienia drogi. W dwóch przypadkach służby zatrzymały również obywateli ZSRR planujących nielegalnie przekroczyć granicę, jeszcze przed ich zbliżeniem do pasa rozdzielającego obydwa państwa; 11 lutego dotyczyło to mieszkańca Moskwy, a 20 sierpnia trzech osób mieszkających w Łotewskiej Socjalistycznej Republice Radzieckiej [LYA 1980: 5].

W 1981 roku zatrzymane zostały 162 osoby, które naruszyły przepisy dotyczące warunków obecności w strefie przygranicznej. Spośród nich 88 otrzymało kary administracyjne. Zatrzymano również 3 obywateli PRL za nielegalne przekroczenie granicy. W dniu 10 maja, 25-letnia kobieta, jak stwierdzono pod wpływem alkoholu, weszła na teren ZSRR. Uznano, iż „W zakresie pracy operacyjnej nie wzbudzała ona zainteresowania i została przekazana przedstawicielom polskich pograniczników" [LYA 1981b: 4]. Następnie 8 sierpnia na jeziorze Gaładuś (Galadusys) dwoje obywateli polskich przepłynęło granicę na rowerze wodnym. Natychmiast po zejściu na brzeg zostali oni zatrzymani, po czym także przekazano ich stronie polskiej [LYA 1981b].

Nieznanym faktem w polskiej literaturze jest wkroczenie, 13 grudnia 1982 roku, na teren ZSRR polskich żołnierzy. Dokonała tego grupa 5 wojskowych pod dowództwem kapitana Mariana Z. Funkcjonariusze służb radzieckich potraktowali tę kwestię jednak z umiarkowanym zrozumieniem. Jak wynika ze sprawozdania KGB, żołnierze byli w stanie nietrzeźwym i weszli na teren państwa radzieckiego w wyniku zagubienia drogi oraz utraty orientacji. Było to $\mathrm{w}$ tym roku jedyne nielegalne przekroczenie 
granicy. Natomiast za naruszenie zasad przebywania w strefie przygranicznej zatrzymano 305 osób, z czego 98 poniosło kary administracyjne [LYA 1982b: 4].

W 1983 roku nieco zwiększyła się liczba prób nielegalnego przekroczenia granicy. Dnia 12 marca, 27-letni polski milicjant, bezpartyjny, będąc w stanie nietrzeźwym zabłądził i wkroczył na radzieckie terytorium. Następnie 4 lipca, 20-letni mieszkaniec Aleksandrowa, który wyjaśniał, że chciał zobaczyć jak wygląda granica, nieświadomie wszedł na terytorium ZSRR. W dniu 13 lipca, 20-letni uczeń z Suwałk będąc w stanie nietrzeźwym, w ciemnościach stracił orientację i znalazł się na radzieckim terytorium [LYA 1983b: 4-5]. Wyraźnie więc przypadki te nie miały celowego charakteru, a wynikały z innych przyczyn. Brak było więc działań, które ukierunkowane byłyby świadomie na dostanie się do sąsiedniego państwa, $\mathrm{z}$ jednej lub drugiej strony. Jednocześnie na terenie rejonu zatrzymano 126 osób, które naruszyły zasady przebywania w terenie przygranicznym. $\mathrm{Z}$ tej liczby 99 zostało pociągniętych do odpowiedzialności administracyjnej [LYA 1983b: 5].

\section{Rejon łoździejski w perspektywie realizacji polityki władz centralnych wobec wydarzeń w Polsce}

Bardzo poważne obawy, w 1980 roku, wzbudziły wśród komunistów radzieckich strajki w Polsce, powstanie NSZZ „Solidarność, proces demokratyzacji życia publicznego oraz wzrost religijności. Odczuwano to jako zagrożenie, które może dać początek podobnym przemianom w ZSRR. Pewnym zaskoczeniem dla KGB był fakt, iż w przygranicznym rejonie łoździejskim wydarzenia w PRL nie pobudziły do podobnych działań. W dokumencie z 10 grudnia 1980 roku wyjaśniano ten fakt następująco „Pomimo bliskości Polski, dużego docinka granicy państwowej z PRL, w rejonie liczba mieszkańców narodowości polskiej jest nieznacząca. W rejonie żyje 258 Polaków, co stanowi 0,67\% od ogólnej liczby ludności. W rejonie nie ma polskich wsi lub osiedli. W ani jednej ze szkół nie prowadzone są zajęcia w języku polskim. Nie ma kościoła, w którym liturgia lub kazania byłyby w języku polskim”. Konkludowano więc „Antyspołecznych, antyradzieckich czy innych niepożądanych zachowań w rejonie w związku z wydarzeniami w PRL nie odnotowano" [LYA 1980: 3]. Wyraźnie więc sytuacja na tym terenie różniła się od położenia w dwóch rejonach zdominowanych przez ludność polską, czyli solecznickim i wileńskim. Odnotowano tam przypadki strajków, rozpowszechniania materiałów poświęconych 
„Solidarności”, zrywania flag państwowych, negatywnych wobec władz wypowiedzi obywateli, zapowiedzi bojkotu wyborów [Bobryk 2014: 31-58].

Pośrednim, zapewne, wpływem procesów zachodzących w Polsce na zachowania mieszkańców, było powszechniejsze wyrażanie negatywnych opinii dotyczących niedoborów w zaopatrzeniu sieci handlowych. We wcześniejszych dokumentach KGB nie odnotowywało takich zdarzeń. Natomiast w sprawozdaniu z działalności za 1981 roku stwierdzono „Nieco negatywny wpływ na sytuację operacyjną wywierają różnorodne dyskusje w związku $\mathrm{z}$ wystąpieniem komplikacji w zabezpieczeniu dostępu ludności do mięsnych i mlecznych produktów oraz innych rodzajów towarów szerokiego zastosowania" [LYA 1981b: 3]. Prawdopodobnie w 1981 roku na terenie rejonu łoździejskiego miał miejsce jeden strajk, ale brak jest szczegółów na ten temat. Jedynie w sprawozdaniu $\mathrm{z}$ działalności KGB, wymieniając rodzaje sygnałów uzyskanych z sieci agenturalnej wskazano „o przerwaniu pracy - I” [LYA 1981b: 3]. Nie ma jednak żadnej uszczegółowiającej informacji, ani nawet stwierdzenia czy sygnał został potwierdzony. Zatrzymano natomiast dwóch sprawców, sprofanowania flagi ZSRR, dokonanego 2 maja 1981 roku w Lejpunach (Leipalingis). Byli to członkowie Wszechzwiązkowego Leninowskiego Komunistycznego Związku Młodzieży. Otrzymali oni wyroki 2,5 lat więzienia w zawieszeniu [LYA 1981b].

Po wprowadzeniu stanu wojennego w Polsce, KGB obawiało się wzrostu napięcia. W planie pracy na 1982 roku stwierdzano „W związku z zaostrzeniem sytuacji w PRL, w przypadku wytworzenia się konfliktowych sytuacji można oczekiwać masowego przejścia przez granicę do Związku Radzieckiego mieszkańców PRL ze środowisk mniejszości narodowych i byłych obywateli ZSRR" [LYA 1982a: 3]. Zalecano również obserwację sytuacji w rejonie w perspektywie reakcji mieszkańców na rozwój sytuacji w Polsce. Zwracano uwagę na potrzebę szczególnej czujności „W związku z podejmowanymi przez polski rząd środkami dla stabilizacji położenia w PRL w celu szybkiego ujawnienia możliwych nawarstwiających się negatywnych procesów wśród różnych kategorii osób i lokalizacji tych przejawów" [LYA 1982a: 12].

W sytuacjach wyjątkowych, dotyczących zwłaszcza przypadków losowych, istniała możliwość przekroczenia granicy korzystając z uproszczonych procedur. Dotyczyło to kilku, czasami kilkunastu osób rocznie. W 1981 roku skorzystało z tej możliwości 3 obywateli ZSRR i 1 PRL. We wszystkich przypadkach związane to było z uczestnictwem w uroczystościach pogrzebowych bliskiej rodziny [LYA 1981b: 5]. W planie pracy na 1982 rok postanowiono poddać szczególnej obserwacji i sprawdzeniu 
osoby korzystające z możliwości uproszczonego przejścia granicy. Stawiano zadanie „Wyjaśnić, czy nie wykorzystują one tego kanału dla kontrabandy, przerzutu szkodliwych ideologicznie materiałów, dla spotkania z obywatelami krajów kapitalistycznych, działaczami «Solidarności» i innej wrogiej działalności. Szczególną uwagę zwrócić na sprawdzenie osób, które uproszczonym sposobem przejścia przez granicę przemieszczały się wielokrotnie, wyjeżdżając do dalszych regionów PRL" [LYA 1982a: 6]. Postawione zadanie okazało się bezprzedmiotowe, gdyż w ciągu całego roku nikt nie skorzystał z takiej możliwości przekroczenia granicy [LYA 1982b: 3]. Niemniej zadanie to wyznaczono również na 1983, pomijając tylko aspekt spotkań z działaczami „Solidarności” [LYA 1983a: 5]. We wskazanym czasie z wykorzystaniem uproszczonych procedur granicę przekroczyło 5 obywateli PRL [LYA 1983b: 2]. Brak natomiast jest informacji w dokumentach KGB, by ich zachowanie w jakikolwiek sposób naruszyło obowiązujące w ZSRR zasady pobytu.

\section{Kontakty mieszkańców z obywatelami krajów zachodnich}

Kontakty z obywatelami krajów zachodnich odbywały się głównie poprzez wymianę korespondencji. Osobiste spotkania na terenie rejonu były sporadyczne, uwarunkowane różnymi ograniczeniami i będące w polu bezpośredniego rozpracowywania przez sieć agenturalną. W rejonie łoździejskim, w 1979 roku, ustalono, iż 914 osób prowadziło korespondencję z obywatelami „krajów kapitalistycznych”. Z tego najwięcej z USA - 529, Kanady - 170 i Wielkiej Brytanii - 45 oraz RFN - 45. Oceniano, iż korespondencja nosi przede wszystkim „rodzinno-bytowy charakter”. Ponadto odnotowano nadejście 107 paczek dla 74 osób, z czego 36 otrzymało je po raz pierwszy [LYA 1979: 2-3]. Zauważono, iż rejon legalnie odwiedziło 4 obywateli krajów kapitalistycznych i 2 nielegalnie [LYA 1979: 3]. W 1980 roku wzrosła skala korespondencji do 936 osób. Kierunki skąd przede wszystkim nadchodziły listy były takie same. Z USA 529, Kanady 171, Wielkiej Brytanii 48. Paczki nadeszły do 108 mieszkańców, z czego 60 po raz pierwszy [LYA, 1980: 2]. W następnym roku odnotowano ograniczenie korespondencji do 896 osób. Z USA kontakt utrzymywało 522 mieszkańców, Kanadą 164, RFN 45. Wzrosła natomiast liczba odbiorców przesyłek towarowych i było ich 112 [LYA 1981b: 2]. Podobna tendencja utrzymała się w 1982 roku ponieważ 789 osób korespondowało $\mathrm{z}$ osobami mieszkającymi w krajach zachodnich. Z tej liczby najwięcej dotyczyło USA 490, Kanady 135, RFN 37. 
Natomiast liczba osób otrzymujących paczki wzrosła do 130 [LYA 1982b: 2]. W 1983 ponownie zmniejszyła się liczba osób utrzymujących korespondencję do 743. Nadal najwięcej osób otrzymywało listy z USA 442, Kanady 138, RFN 54. Więcej odbiorców otrzymywało też paczki - 131 [LYA 1983b: 1]. Interesujące, iż $\mathrm{w}$ rocznych wykazach nie uwzględniano prowadzonej korespondencji z PRL, co odróżniało ten rejon od jednostek, gdzie Polacy stanowili znaczącą część mieszkańców.

O skali obaw służb dotyczących kontaktów obywateli z obcokrajowcami, co traktowano jako zagrożenie dla bezpieczeństwa państwa, świadczy sprawa operacyjnego rozpoznania o kryptonimie „Fotograf”. Ustalono, iż mieszkaniec rejonu łoździejskiego spotkał się latem 1979 roku z turystami będącymi obywatelami RFN. W efekcie otrzymał od nich aparat fotograficzny. KGB postanowiło więc rozpocząć agenturalno-operacyjne rozpracowywanie tworząc siatkę agentów wokół danej osoby. Planowano określić, jakie wrogie dla systemu cele może osiągnąć obywatel przy użyciu aparatu fotograficznego [LYA 1979, s. 7]. W sprawozdaniu za 1980 informację na ten temat uznano za jeden $\mathrm{z}$ ważniejszych sygnałów uzyskanych ze źródeł operacyjnych. Jednocześnie stwierdzono, iż w wyniku rozpracowania ustalono, iż obywatel ten nie potrafi obsługiwać aparatu fotograficznego i w związku z tym nim się nie posługuje [LYA 1980: 9]. Nie zakończyło to jednak działań operacyjnych. Wyznaczono bowiem dwóch agentów, by sprawdzili, czy nie zajmuje się on pozyskiwaniem informacji stanowiących tajemnicę wojskową lub państwową [LYA 1981a: 8]. Jego rozpracowywanie zakończono dopiero u schyłku 1981 roku, uznając, iż nie prowadzi on żadnej działalności, która budziłaby zainteresowanie kontrwywiadu [LYA 1981b: 7].

\section{Osoby pod szczególnym nadzorem}

Na terenie rejonu łoździejskiego w 1979 roku mieszkały 253 osoby karane za szczególnie ciężkie antypaństwowe działania (w tym 16 byłych uczestników antyradzieckiego ruchu oporu, określanych w sprawozdaniach jako „zalegalizowanych uczestników zbrojnych band nacjonalistycznych”). Wobec $6 \mathrm{z}$ nich prowadzono sprawy operacyjnego rozpracowania. Ponadto, było ponad 800 osób, które wróciły z zesłania. KGB oceniało, iż nie podejmowali oni już wrogiej działalności, co potwierdzały dane uzyskiwane od agentury [LYA 1979: 2]. Niemniej jako osoby, które w przeszłości występowały przeciwko władzy radzieckiej, znajdowały się pod specjalną 
obserwacją. Należy zwrócić uwagę, iż wśród osób wcześniej sądzonych za działalność antypaństwową było 7 agentów KGB [LYA 1979]. W sprawozdaniach uwzględniano również obecność repatriantów, których było 29, 16 Niemców, 3 wskazujących swe niemieckie pochodzenie, 1 osobę bez obywatelstwa, 1 obywatela PRL. Zwrócono uwagę, iż nikt z Niemców nie starał się o pozwolenie na przesiedlenie do RFN [LYA 1979: 3]. Sytuacja po roku uległa niewielkiej zmianie, gdyż jeden z Niemców, niejaki Kunevičius wyjechał $\mathrm{w}$ sprawach prywatnych do RFN i odmówił powrotu do ZSRR. Konsekwencją tego było złożenie wniosku przez jego żonę o zgodę na opuszczenie Związku Radzieckiego [LYA 1980: 3]. Jak wynika z analizy sprawozdań za kolejne lata, decyzja w tej sprawie była odwlekana.

W 1983 roku liczba mieszkańców rejonu skazanych w przeszłości za antypaństwowe działania zmniejszyła się do 245 (w tym 15 byłych uczestników antyradzieckiego podziemia), z czego 94 miało powyżej 70 lat, a tylko 3 poniżej 50. Świadczyło to o tym, iż w na tym obszarze w poprzedzających analizowany okres latach praktycznie nie występowały formy radykalnego oporu przeciwko władzy radzieckiej. KGB zaś obserwowało przede wszystkim tych, którzy w okresie wojny i pierwszych latach powojennych angażowali się w działania przeciwko systemowi. W latach 1973-1983 organy bezpieczeństwa poddały profilaktyce, czyli po pozyskaniu informacji o niepożądanych zachowaniach przeprowadziły działania uprzedzające i ostrzegające, łącznie 36 osób, które nadal mieszkały na terenie rejonu. Jednocześnie liczba Niemców zmniejszyła się do 12, 3 wskazujących niemieckie pochodzenie i jednego którego określano jako „Z wschodnich Niemców”. Ponadto była osoba bez obywatelstwa. Nie odnotowano natomiast zamieszkiwania tego terenu przez obywateli PRL [LYA 1983b: 2]. Nie wymieniano też w sprawozdaniach osób narodowości polskiej jako stanowiących potencjalne zagrożenie.

\section{Życie religijne}

W rejonie łoździejskim funkcjonowało 15 kościołów katolickich. Posługę duszpasterską sprawowało w nich 14 duchownych. Wśród nich 4 było wcześniej skazanych. Z oburzeniem odnotowywano, że realizowana była nauka religii prowadzona przez "reakcyjnie nastawionych księży” i „kościółkowców”, a nieletnich angażowano do uczestnictwa w praktykach i służeniu w świątyni. Jak oceniano „Zauważalna była wysoka religijność ludności” [LYA 1979:2]. Stwierdzano też „Część księży stale narusza przepisy 
prawne dotyczące kultu, zapraszają reakcyjnie nastrojonych kaznodziejów i nielegalnych księży, którzy wykorzystują ambonę kościoła do wrogich celów, oczerniają szkoły, obrażają ateistów. (...) Niektórzy księża starają się przewodzić ruchowi walki z pijaństwem, żądają od wiernych pisemnych oświadczeń o tym, że nie będą spożywać alkoholu. Część księży narusza przepisy meldunkowe: u nich długi czas bez zgłoszenia mieszkają obcy ludzie" [LYA 1980: 2].

W analizowanym okresie wykazywano nowe inicjatywy dotyczące posadowienia w miejscach publicznych krzyży bez uzyskania zezwolenia. Decyzją władz administracyjnych były one niezwłocznie usuwane. Prowadzono szereg działań mających na celu wychowanie religijne młodzieży, co również spotykało się z przeciwdziałaniem służb. Wyraźnie jednak w 1983 roku pojawiły się symptomy obywatelskiego nieposłuszeństwa. W raporcie wręcz stwierdzano, iż „zaktywizowała się grupa księży - ekstremistów”. Przykładowo, 20 marca odbyła się manifestacja młodzieży pod budynkiem KGB w Łoździejach żądających uwolnienia zatrzymanego ks. Juozasa Zdebskisa. W dniu 28 czerwca, we wsi Paveisininkai (Komisja Standaryzacji Polskich Nazw Geograficznych nie podaje jej polskiej nazwy [Zych 2013]) trzech duchownych odprawiło mszę w niezarejestrowanym budynku sakralnym. Liturgia została przerwana przez organy bezpieczeństwa. Za organizację tego wydarzenia religijnego ukarano 4 młodych ludzi 15 dniami aresztu, a ks. Zdebskisa pozbawiono prawa jazdy na 2 lata.

W kilku kościołach przeprowadzono zbiórkę podpisów pod petycją o uwolnienie księży Alfonsasa Svarinskasa i Sigitasa Tamkevičiusa aresztowanych 26 stycznia. Za organizowanie procesji 1 listopada, z kościoła na cmentarz, ks. Plioraitis ukarany został grzywną. Agentura KGB odnotowała z oburzeniem, iż podczas kazania duchowny oświadczył, iż kara została na niego nałożona niesprawiedliwie. Przygotowano też szereg materiałów, które zostały opublikowane w wydawanej w drugim obiegu „Kronice Kościoła Katolickiego na Litwie” (Lietuvos katalikų bažnyčios kronika), [LYA 1983b: 3, 5-6; Wołowski, Korzeniewska 2006]. Niewątpliwie ożywienie działalności religijnej wykraczające poza dopuszczone w ZSRR ramy $\mathrm{w}$ jakimś stopniu było skutkiem zmian zachodzących w Polsce; nie tylko ustępstw władzy w niektórych sferach życia, ale również zwiększonej aktywności Kościoła katolickiego, jak i działań papieża Jana Pawła II, a zwłaszcza jego pielgrzymek do Polski. 


\section{Podsumowanie}

W okresie funkcjonowania PRL i ZSRR upowszechniana była teza o przyjaźni i braterstwie obydwu państw oraz narodów. Miało to jednak wyłącznie charakter oficjalny o zabarwieniu ideologicznym. Faktycznie ograniczano i kontrolowano autentyczne kontakty mieszkańców, w tym na pograniczu. KGB bezpośrednio odpowiadała za nadzór, infiltrację ludności oraz wymuszanie postępowania zgodnie z wytyczonymi przez KPZR wzorami. Pomimo tego jednak wiele form aktywności społecznej było niezależnych od tych działań, a procesy zachodzące w Polsce odbijały się również w pewnym stopniu na zachowaniach i postawach mieszkańców przygranicznego rejonu łoździejskiego LSRR (ZSRR).

„Zderzenie kulturowe promieniuje na całokształt wartości, postaw i zachowań społecznych. Mają one swoje określone odzwierciedlenie w gospodarce, życiu społecznym, postawach życiowych, sympatiach, antypatiach, migracjach, w życiu politycznym" [Sadowski 1992:6]. By zmniejszyć oddziaływanie przemian zachodzących w Polsce władze radzieckie ograniczały wzajemne kontakty obywateli, zwłaszcza w czasach przełomu politycznego, jakim były strajki, powstanie „Solidarności” i wprowadzenie stanu wojennego. Pomimo ograniczeń i kontroli, informacje, idee, wzory postępowania w pewnym stopniu docierały do mieszkańców przygranicznego rejonu łoździejskiego. Ich wpływ jednak był ograniczany zarówno przez działania aparatu władzy, jak też nie bez znaczenia był fakt zróżnicowania narodowego po obydwu stronach granicy, przy świadomości trudnych wzajemnych relacji w przeszłości. Nie sprzyjało to rozwojowi kontaktów oraz w mniejszym stopniu prowadziło do przejmowania wzorów zachowań.

\section{Bibliografia}

Aleksandrow J. (1949), ZSRR - przodująca demokracja świata, Warszawa.

Anušauskas A. (2008), KGB Lietuvoje. Slaptosios veiklos bruožai, Vilnius.

Anušauskas A. (2006), Teroras ir nusikaltimai žmoniškumui = Terror and crimes against Humanity. Pirmoji sovietinè okupacija (1940-1941), Vilnius.

Babiński G. (2015), Pogranicza, migracje, sasiedztwa - państw, społeczeństw, narodów, kultur, [w:] M. Bieńkowska, W. Żelazny (red.), Pogranicza. Księga jubileuszowa profesora Andrzeja Sadowskiego, Białystok.

Babiński G. (1994), Pogranicze etniczne, pogranicze kulturowe, peryferie. Szkic wstępny problematyki, „Pogranicze. Studia Społeczne”, t. 4. 
Błaszczyk G. (1992), Litwa współczesna, Warszawa - Poznań.

Bobryk A. (2005), Odrodzenie narodowe Polaków w Republice Litewskiej 1987-1997, Toruń.

Bobryk A. (2014), Polacy na Wileńszczyźnie wobec systemu radzieckiego. Lata osiemdziesiate XX wieku w świetle raportów KGB, „Doctrina. Studia Społeczno-Polityczne”, nr 11.

Buchowski K. (2006), Litwomani i polonizatorzy. Mity, wzajemne postrzeganie i stereotypy w stosunkach polsko-litewskich w pierwszej połowie XX wieku, Białystok.

Eberhardt P. (1997), Przemiany narodowościowe na Litwie, Warszawa.

Fedorowicz J. (2008), Solidarność - 500 pierwszych dni, Warszawa.

Konstytucja Związku Socjalistycznych Republik Radzieckich (1978), Warszawa.

Кравченко Л. (1980), СССР в авангарде борьбы за мир и разрядку международной напряженности, „Знание”, Минск.

Lietuvos Ypatyngasis Archyvas (LYA), (1979), План агентурно-оперативньхх и организаиионных мероприятий Лаздийского РО КГБ Литовской ССР на 1980 год, F. K-11, ap. 1, b. 1730, 1. 133-152.

LYA (1980), Отчет агентурно-оперативной деятельности Лаздийского РО КГБ Лит. ССР за 1980 г., F. K-11, ap. 1, b. 1730, 1. 115-127.

LYA (1981a), План агентурно-оперативных и организационных мероприятий Лаздийского РО КГБ Лит. ССР на 1981 год, F. K-11, ap. 1, b. 1730, 1. 10-21

LYA (1981b), Отчёт об итогах агентурно-оперативной работь Лаздийского РО КГБ Лит. ССР за 1981 год, F. К-11, ap. 1, b. 1730, 1. 44-54.

LYA (1982а), План агентурно-оперативных и организационных мероприятий Лаздийского РО КГБ Литовской ССР на 1982 год, F. K-11, ap. 1, b. 1730, 1. 59-71.

LYA (1982b), ), Отчёт об итогах агентурно-оперативной работы и работы скадрами Лаздийского РО КГБ Лит. ССР за 1982 год, F. К-11, ap. 1, b. 1730, 1. 76-87.

LYA (1983a), План агентурно-оперативных, организационных мероприятий и мероприятий по работе с кадрами Лаздийского РО КГБ Лит. ССР на 1983 год, F. К-11, ap. 1, b. 1730, 1. 90-102.

LYA (1983b), Отчет об агентурно-оперативной работе с кадрами Лаздийского РО КГБ Литовской ССР за 1983 год, F. K-11, ap. 1, b. 1730, 1. 148-161.

Łossowski P. (1991), Polska-Litwa. Ostatnie sto lat, Warszawa.

Mendras H. (2004), Elementy socjologii, Wrocław.

Mikłaszewicz I. (2001), Polityka sowiecka wobec Kościoła katolickiego na Litwie 1944-1965, Warszawa.

Požarskas M. (1984), Współpraca przyjaciół zrodzona przez socjalizm, Kaunas.

Sadowski A. (1992), Pogranicze. Studia społeczne. Zarys problematyki, „Pogranicze. Studia Społeczne”, t. 1.

Sadowski A. (2014), Socjologia pogranicza $w$ warunkach społeczeństwa pluralistycznego, [w:] M. Zielińska, B. Trzop. (red.), Transgraniczność w perspektywie socjologicznej. Pogranicza i centra wspótczesnej Europy, Zielona Góra.

Солженицын А. (2009), Архипелаг ГУЛАГ. Полное издание в одном томе, Москва. 
Sztompka P. (2012), Socjologia. Analiza społeczeństwa, Kraków.

Ślusarczyk J. (1994), Granice Polski w XX wieku (koncepcje, realizacja, zagrożenia), Toruń.

Tininis V. (2009), Komunistinio režimo ịtvirtinimas Lietuvoje ir jo nusikaltimai = The establishment of the communist regime in Lithuania and its crimes. Antroji sovietine okupacija (1944-1953), Vilnius.

Wiatr J. J. (2009), Socjologia polityki, Warszawa.

Wołowski P., Korzeniewska K. (2006), Jak służąc Panu Bogu oszukać KGB. Rozmowy z twórcami „Kroniki Kościoła Katolickiego na Litwie”, Warszawa.

Zych M. (red.), (2013), Urzędowy wykaz polskich nazw geograficznych świata, Warszawa.

\section{SUMMARY}

Times of a breakthrough. The Lithuanian-Polish borderland under the KGB LSSR operations between 1979 and 1983 in the Lazdijai region

At the time of the Polish People's Republic and the Soviet Union there was a thesis of friendship and brotherhood disseminated between the two countries and nations. This was, however, a purely official belief based on the ideology of those times. In fact communication between people, including those inhabiting the borderland was restricted and controlled. The KGB was directly responsible for supervision, infiltration of people and enforcement of the CPSU patterns of behaviour. Despite the KGB operations, many forms of social activities were not disrupted by the KGB. Moreover, the processes taking place in Poland had to some extent an impact on behaviour and attitudes of the residents of the Lazdijai region (LSSR). To reduce this, the Soviet authorities limited interactions between both nations, especially in times of political breakthrough resulting in strikes, the rise of „Solidarity”, and the imposition of martial law.

KEYwORDs: KGB, USSR, LSSR, Poland, borderland, communism, intelligencer 